\title{
Manganese induced parkinsonism: an outbreak due to an unrepaired ventilation control system in a ferromanganese smelter
}

\author{
J-D WANG, ${ }^{1}$ C-C HUANG, ${ }^{2}$ Y-H HWANG, ' J-R CHIANG, ${ }^{1}$ J-M LIN, ${ }^{1}$ J-S CHEN ${ }^{\prime}$
}

From the Department of Internal Medicine and Clinical Pathology, National Taiwan University Hospital, and Center for the Research of Environmental and Occupational Diseases,' Graduate Institute of Public Health, National Taiwan University College of Medicine, and Department of Neurology, ${ }^{2}$ Chang-Gung Memorial Hospital, Taipei, Taiwan

ABSTRACT Several cases of parkinsonism were found in a ferromanganese smelter after their ventilation system had broken down and had not been repaired for eight months in 1985. To determine the aetiology and prevalence of parkinsonism, 132 workers were submitted to thorough medical examination and estimated air concentrations of carbon monoxide and manganese at different worksites. Only six of eight workers performing electrode fixation or welding during $1985 \mathrm{~S}^{\mathrm{D}}$ developed parkinsonism. They were exposed for 30 minutes each day, seven days a week, to highs concentrations of air manganese $\left(>28.8 \mathrm{mg} / \mathrm{m}^{3}\right)$. There was a consistent trend between the index of exposure to manganese and signs and symptoms exhibited by extrapyramidal systems. After repair of. the ventilation system, the air concentration of manganese during electrode fixation and weldiog 60 decreased to less than $4.4 \mathrm{mg} / \mathrm{m}^{3}$; furthermore, no new cases of parkinsonism have been observed Workers with parkinsonism recovered partially after removal from original worksites and treatmegrit: with levodopa. It is concluded that the outbreak resulted from exposure to high concentrations manganese fumes through the breakdown of the ventilation system.

In October 1985 a 44 year old ferromanganese smelting worker attended the Chang-Gung Memorial Hospital department of neurology complaining primarily of spastic gait. He had a mask like face, a reduced rate of blinking, clumsiness, micrographia, and bradykinesia. Parkinsonism was diagnosed. Because several other coworkers exhibited similar symptoms, and parkinsonism has been reported to be associated with exposure to manganese, ${ }^{1-8}$ we decided to study the aetiology and prevalence of parkinsonism among workers at this factory.

\section{Material and methods}

The factory has been operating for 18 years and consists of three major departments: the ferromanganese smelting, foundry, and management office. During 1983, the ventilation systems (particularly the air cleaning device) of the three furnaces of the smelting department were not in good working order, The owner ordered a new system and removed the old one in December 1984 but did not discontinue smelt-o ing operations. Owing to delays in the installation of 3 the new equipment, workers were subsequentlyo exposed to raised concentrations of manganese Workers were classified into four groups according too the probability of exposure to manganese at their occupations: degree 0 , office, designing, and packag윽 ing workers; degree 1 , foundry, foundry related, non $\rightarrow$ furnace maintenance workers, and metal cutters, degree 2, furnacemen; and degree 3, furnace foremen and maintenance workers. Air samples were collectedos using personal and area samplers. Manganese concen $\widetilde{O}$ trations were estimated by graphite furnace atomio absorption spectrometry, ${ }^{9}$ and carbon monoxide con $\frac{}{0}$ centrations by direct reading from a Kitagawa COM-4 carbon monoxide analyser.

Each of the 132 workers in the factory underwent as 
comprehensive physical examination that included detailed occupational and medical histories, chest radiography, electrocardiography, liver function tests, blood creatinine assays, and complete blood count. Then 123 were also interviewed for neurological symptoms; blood samples were taken from 68 of these workers to estimate the manganese in whole blood. ${ }^{10}$ The association between exposure to manganese and each neurological symptom was calculated using the chi-squared test for trend. ${ }^{11}$

\section{Results}

An area air sample taken about $3.5 \mathrm{~m}$ from the top of the furnace, where degree 3 workers operate on the electrode, contained $28.8 \mathrm{mg} / \mathrm{m}^{3}$ of manganese, whereas two samples taken near the side of the furnace contained $1.0 \mathrm{mg} / \mathrm{m}^{3}$. According to our field observations, workers who operate on the electrode were probably exposed to manganese fumes higher than $28.8 \mathrm{mg} / \mathrm{m}^{3}$ manganese for at least 30 minutes a day, seven days a week. The air concentration of carbon monoxide was less than $15-60 \mathrm{ppm}$ both near the side and near the top of the furnace.

All furnacemen were men, most of whom had been employed for more than 10 years (table 1). Six of the eight degree 3 workers developed parkinsonism, as diagnosed by standard neurological examination. No cases were found in the other workers. Furnacemen (degree 2) were exposed to $0.5-1.5 \mathrm{mg} / \mathrm{m}^{3}$ manganese, whereas foundry workers who worked in a separate building were exposed to only $0.1 \mathrm{mg} / \mathrm{m}^{3}$. We did not measure manganese concentrations in the management office but exposure was probably even less.
Table 2 shows that the blood manganese concentration increased with exposure. Table 3 shows that the frequency of neurological symptoms and extrapyramidal signs increased with the degree of exposure to manganese and supports the possibility of some early stage cases of parkinsonism. No similar association was found between the degree of exposure and the results of liver function tests, blood creatinine assays, electrocardiograms, and chest radiographs.

\section{Discussion}

Parkinsonism is a symptom complex consisting of bradykinesia, rigidity, tremors, and impaired postural reflexes. Its aetiology includes infections, toxins, pharmacological causes, and other degenerative diseases. ${ }^{12} 13$ That manganese played a causative part in the six cases of parkinsonism among the ferromanganese workers is supported by several observations. All six were below the usual age of onset of ideopathic Parkinson's disease ${ }^{1213}$; two were under 47 and the other four under 40. All six worked in the same occupational setting, where the manganese concentration usually exceeded $28.8 \mathrm{mg} / \mathrm{m}^{3}$, and all but one showed raised blood manganese concentrations (greater than $20 \mu \mathrm{g} / \mathrm{l}$ ). The blood sample of the one patient with $10 \mu \mathrm{g} / \mathrm{l}$ manganese had been taken six months after he had left the company.

Furthermore, it is unlikely that these cases were the result of exposure to other causal agents. The air concentration of carbon monoxide was usually below $60 \mathrm{ppm}$, which normally does not produce a carboxyhaemoglobin concentration higher than $10 \%{ }^{14}$; carboxyhaemoglobin concentrations less than $20 \%$ are

Table 1 General characteristics of workers with different levels of manganese (Mn) exposure

\begin{tabular}{|c|c|c|c|c|}
\hline & \multicolumn{4}{|c|}{ Index of exposure to $M n$} \\
\hline & $0(n=32)$ & $1(n=68)$ & $2(n=24)$ & $3(n=8)$ \\
\hline $\begin{array}{l}\text { \% Male } \\
\text { Age (y) } \\
\text { Months spent at working (current job or factory) } \\
\% \text { Smokers }\end{array}$ & $\begin{array}{l}53 \cdot 1 \\
34 \cdot 4 \pm 9 \cdot 64 \\
85 \pm 67 \\
38\end{array}$ & $\begin{array}{l}95 \cdot 6 \\
39 \cdot 7 \pm 10 \cdot 74 \\
85 \pm 64 \\
59\end{array}$ & $\begin{array}{l}100 \\
46 \cdot 5 \pm 8 \cdot 3 \\
134 \pm 74 \\
67\end{array}$ & $\begin{array}{l}100 \\
40 \cdot 1 \pm 4 \cdot 2 \\
114 \pm 61 \\
88\end{array}$ \\
\hline
\end{tabular}

Table 2 Concentration of blood manganese (Mn) among workers with different exposure categories

\begin{tabular}{|c|c|c|c|c|}
\hline & \multicolumn{4}{|c|}{ Index of exposure to $M n$} \\
\hline & $0(n=17)$ & $1(n=28)$ & $2(n=16)$ & $3(n=8)$ \\
\hline $\begin{array}{l}\text { Mn conc of blood }(\mu \mathrm{g} / \mathrm{l}) \pm 1 \mathrm{SD}: \\
\text { Median } \\
\text { Range } \\
\text { Haemoglobin concentration }(\mathrm{mg} / 100 \mathrm{ml}) \pm 1 \mathrm{SD}: \\
\text { Median } \\
\text { Albumin/globulin ratio } \pm 1 \mathrm{SD}: \\
\text { Median }\end{array}$ & $\begin{array}{l}14 \cdot 9 \pm 9 \cdot 2 \\
12 \cdot 0 \\
3-35 \\
14 \cdot 8 \pm 1 \cdot 5 \\
14 \cdot 7 \\
1 \cdot 4 \pm 0 \cdot 1 \\
1 \cdot 4\end{array}$ & $\begin{array}{l}25 \cdot 2 \pm 8 \cdot 6 \\
22 \cdot 5 \\
13-38 \\
16 \cdot 1 \pm 1 \cdot 3 \\
16 \cdot 2 \\
1 \cdot 4 \pm 0 \cdot 2 \\
1 \cdot 4\end{array}$ & $\begin{array}{l}31 \cdot 3 \pm 15 \cdot 6 \\
28 \cdot 3 \\
13-82 \\
15 \cdot 8 \pm 1 \cdot 4 \\
15 \cdot 8 \\
1 \cdot 4 \pm 0 \cdot 1 \\
1 \cdot 4\end{array}$ & $\begin{array}{l}146 \pm 155 \\
80 \\
10-405 \\
15 \cdot 5 \pm 1 \cdot 0 \\
15 \cdot 3 \\
1 \cdot 6 \pm 0 \cdot 1 \\
1 \cdot 6\end{array}$ \\
\hline
\end{tabular}


Table 3 Prevalence of neurological signs and symptoms among workers stratified by different levels of exposure to manganesie $(M n)$

\begin{tabular}{|c|c|c|c|c|c|}
\hline \multirow[b]{2}{*}{ Symptoms and signs } & \multicolumn{4}{|c|}{ No of workers at different indices of exposure to $\mathrm{Mn}$} & \multirow[b]{2}{*}{$p^{*}$} \\
\hline & $0(n=32)$ & $1(n=64)$ & $2(n=19)$ & $3(n=8)$ & \\
\hline \multicolumn{6}{|l|}{ Signs: } \\
\hline Bradykinesia & 0 & 0 & $\mathbf{0}$ & 6 & $<0.0001$ \\
\hline Rigidity & 0 & 0 & 0 & 6 & $<0.0001$ \\
\hline \multicolumn{6}{|l|}{ Gait abnormality: } \\
\hline Unable to walk backward & 0 & 0 & 0 & 6 & $<0.0001$ \\
\hline Stopping while turning around & 0 & 0 & 0 & 5 & $<0.0001$ \\
\hline Stuttering & 0 & 0 & $\mathbf{0}$ & 5 & $<0.0001$ \\
\hline Tremor & 0 & 1 & 0 & 4 & $<0.0001$ \\
\hline \multicolumn{6}{|l|}{ Symptoms: } \\
\hline Weakness & 4 & 4 & 9 & 7 & $<0.0001$ \\
\hline Cramps in arms and legs & 2 & 7 & 5 & 4 & 0.0012 \\
\hline Loss of libido & 1 & 5 & 4 & 3 & 0.002 \\
\hline Dislike of talking & 2 & 1 & $i$ & 4 & 0.0026 \\
\hline Unable to perform delicate job & 1 & 4 & 3 & 3 & 0.003 \\
\hline Hallucination & 0 & 1 & 0 & 2 & 0.0054 \\
\hline Fatigue & 8 & 15 & 11 & 4 & 0.017 \\
\hline Anorexia & 2 & 7 & 5 & 2 & 0.032 \\
\hline Fatigue, heaviness in legs & 4 & 6 & 4 & 4 & 0.042 \\
\hline Hypersalivation & 2 & 3 & 1 & 3 & 0.046 \\
\hline Muscle cramping pain & 2 & 7 & 4 & 2 & 0.06 \\
\hline Insomnia & 2 & 9 & 4 & 2 & 0.08 \\
\hline Drowsiness & 8 & 5 & 4 & 0 & $0 \cdot 16$ \\
\hline Thirst & 6 & 15 & 3 & 1 & 0.67 \\
\hline Abdominal cramps & 0 & 6 & 1 & 0 & 0.70 \\
\hline Headache & 6 & 7 & 5 & 1 & 0.87 \\
\hline Irritability & 6 & 7 & 4 & 1 & 0.90 \\
\hline
\end{tabular}

not believed to result in parkinsonism. ${ }^{15}$ In addition, no incidents of carbon monoxide poisoning resulting in parkinsonism sequelae ${ }^{16}$ had occurred in the factory since its establishment in 1967. Furthermore, no evidence of other medical problems, such as infections of the central nervous system, tumours, hypoxia, or Wilson's disease, was observed in these six workers. Finally, all six cases were diagnosed between August 1985 and May 1986 after the breakdown of the ventilation system (December 1984); no cases had been diagnosed before then, nor have any new cases been diagnosed since the installation of a new system in August 1986. Because the only cases of parkinsonism in the factory's 20 year history developed during the short period of 20 months when the ventilation system was not operating properly, we conclude that manganism may be attributed to the faulty and removed ventilation system, which resulted in daily worker exposure to high concentrations of manganese fumes.

The poor correlation found between blood concentration of manganese and duration of employment is in accordance with Tsalev et al. ${ }^{10}$ At the same time, we did find a clear relation between the level of manganese exposure and the blood concentration of manganese, as indicated in table 2 . In fact, only four of 17 employees in the degree 0 exposure group had a blood manganese concentration above $20 \mu \mathrm{g} / \mathrm{l}$; this is par- tially explained by the fact that these four worfere were occasionally required to enter high expostre work areas. These results concur with data from and monkeys ${ }^{17}$ and from other manganese workers. Blood manganese concentration may therefore be used as an indicator of current environmenta exposure but not of chronic exposure.

Although some authors have tried to explai $\overrightarrow{\vec{\theta}}$ individual susceptibility to manganese as the result of nutritional deficiency and variation in absorptio efficiency due to conditions such as anaemia ${ }^{19}$ and low. albumin/globulin ratios, ${ }^{20}$ we did not find any evidenco of abnormal concentrations or albumin/globulig ratios among the cases with parkinsonism whe compared with degree 2 workers or other (non-parkin?. sonism) degree 3 workers.

On completion of the epidemiological study, the factory owner responded and took action to enhanoe dilutional ventilation and implement a new system of local ventilation. Subsequently, air manganese cone centrations were usually below $1.6-2 \cdot 1 \mathrm{mg} / \mathrm{m}^{3}$, with short term concentrations of around $2.9 \mathrm{mg} / \mathrm{m}^{3}$ during the electrode welding operation; the foremen wert exposed to $4.4 \mathrm{mg} / \mathrm{m}^{3}$ manganese while they operated on the electrodes. There have been no new cases of parkinsonism since implementation of the protective measures. The workers with parkinsonism were removed from their original jobs and treated with 
levodopa, which appeared to improve the neurological symptoms by $50 \%$, as measured by the modified Columbia Scales. $^{21}$

This study was supported by the Department of Health, Executive Yuan, ROC, grant No 78-21.

\section{References}

1 Smyth LT, Ruhf RC, Whitman NE, Dugan T. Clinical manganism and exposure to manganese in the production and processing of ferromanganese alloy. J Occup Med 1973;15:101-9.

2 Tanaka S, Lieben J. Manganese poisoning and exposure in Pennsylvania. Arch Environ Health 1969;19:674-84.

3 Rodier J. Manganese poisoning in Moroccan miners. Br J Ind Med 1955;12:21-35.

4 Schuler $\mathrm{P}$, Oyanguren $\mathrm{H}$, Maturana V, et al. Manganese poisoning: environmental and medical study at a Chilean mine. Industrial Medicine and Surgery 1957;26:167-73.

5 Horiguchi S, Utsonomiya T, Kasahara A, et al. A survey of the actual conditions of factories handling manganese compounds. Japanese Journal of Industrial Health 1966;8:333-42.

6 Suzuki Y, Nishiyama K, Suzuki Y, et al. The effects of chronic manganese exposure on ferromanganese workers. Shikoku Acta Med 1973;29:412-24, 433-8.

7 Saric M, Markicevic A, Hrustic O. Occupational exposure to manganese. Br J Ind Med 1973;34:114-8.

8 Whitlock CM Jr, Amuso SJ, Bittenbender JB. Chronic neurological disease in two manganese steel workers. Am Ind Hyg Assoc J 1966;27:454-9.

9 National Institute of Occupational Safety and Health. Manganese and compounds. NIOSH manual of analytic methods. 2nd ed. Cincinnati: NIOSH, 1977:S5-1-6. (DHEW (NIOSH) publication No 77-157.)
10 Tsalev DL, Langmyhr FJ, Gunderson N. Direct atomic absorption spectrometric determination of manganese in whole blood of unexposed individuals and exposed workers in a Norwegian manganese alloy plant. Bull Environ Contam Toxicol 1977; 17:660-6.

11 Mantel N. Chi-square tests with one degree of freedom: extensions of Mantel-Haenszel procedure. Journal of the American Statistical Association 1963;58:690-700.

12 Koller WC. Classification of parkinsonism. In: Koller WC, ed. Handbook of Parkinson's disease. New York: Marcel Dekker Inc, 1987:51-80.

13 Marsden CD. Basal ganglia and motor dysfunction. In: Asbury AK, Mekhann GM, McDonald WI, eds. Diseases of the nervous system. Philadelphia: WB Saunders, 1986:394-400.

14 Stewart RD. The effect of carbon monoxide on humans. Annu Rev Pharmacol Toxicol 1975;15:409-23.

15 Gilbert GJ, Glaser GH. Neurologic manifestations of chronic carbon monoxide poisoning. $N$ Engl J Med 1959;261:1217-20.

16 Ringel SP, Klawans HL. Carbon monoxide-induced parkinsonism. J Neurol Sci 1972;16:245-51.

17 Ulrich CE, Kinehart W, Brandt M. Evaluation of the chronic inhalation toxicity of a manganese oxide aerosol. III-Pulmonary function, electromyograms, limb tremor, and tissue manganese data. Am Ind Hyg Assoc J 1979;40:349-53.

18 Roels H, Lauwerys R, Gemet P, et al. Relationship between external and internal parameters of exposure to manganese in workers from a manganese oxide and salt producing plant. $\mathrm{Am} \mathrm{J}$ Ind Med 1987;11:297-305.

19 Mena I, Horiuchi K, Burke K, Cotzias GC. Chronic manganese poisoning: individual susceptibility and absorption of iron. Neurology 1969;19:1000-6.

20 Hassanein M, Ghaleb HA, Haroun EA, Hegazy MR, Khayyal MAH. Chronic manganism: preliminary observations on glucose tolerance and serum proteins. Br J Ind Med 1966;23: 67-70.

21 Huang CC, Chu NS, Lu CS, et al. Chronic manganese intoxication. Arch Neurol (in press). 